\title{
PENGARUH PEMBERIAN DOLOMIT DAN PEMUPUKAN NPK TERHADAP PERTUMBUHAN DAN HASIL OKRA (Abelmoschus esculentus L.) PADA TANAH HISTOSOL
}

\author{
Iwandikasyah Putra $^{* 1)}$, Jasmi ${ }^{1)}$, Oki Setiawan ${ }^{2)}$ \\ ${ }^{1}$ Program studi Agroteknologi Fakultas Pertanian Universitas Teuku Umar, Meulaboh 23615 \\ ${ }^{2}$ Mahasiswa Program studi Agroteknologi Fakultas Pertanian Universitas Teuku Umar, Meulaboh 23615 \\ *) Email Korespondensi: iwandikasyahputra@utu.ac.id
}

\begin{abstract}
Histosol is an organic soil with a high acidity value ( $\mathrm{pH} 4.5)$ and low levels of nutrients $N, P$, and $K$ that is effects to plant growth and yield. This study aims to examine the effect of dolomite and NPK fertilization on the growth and yield of Okra (Abelmoschus esculentus L.) on Histosol soil. This research was conducted in the Experimental Garden of the Faculty of Agriculture, Teuku Umar University, West Aceh. This study used a factorial $4 x 4$ randomized block design (RBD) with 3 replications. The factors studied include: 1) Dolomite factor (D) consists of 4 levels, namely: DO= without liming, D1=22.5 grams/polybag, D2= 45 grams/ polybag, D3= 67.5 grams / polybag; 2) NPK fertilizer factor $(N)$ consists of 4 levels, namely: $N O=$ zero $N P K$ fertilizer application, $N 1=11.25$ gram $/$ polybag, $N 2=18.75$ grams $/$ polybag, $N 3=26.25$ grams/polybag. The results showed that dolomite dose had a very significant effect on plant height, stem diameter and number of leaves of okra plants aged 15, 30, 45 and $60 \mathrm{HST}$. Very significant effect on the length of the okra fruit aged 73 HST and significant effect on the weight of the fruit age 73 HST, but no significant effect on fruit diameter, number of fruit age and production per hectare (tons) $73 \mathrm{HST}$. NPK fertilizer has a very significant effect on plant height and stem diameter aged 15, 30, 45 and 60 HST. Very significant effect on fruit length and diameter okra fruit aged 73 HST. Not significant effect on the number of fruits, fruit weight and per hectare production (tons) of okra aged 73 HST. There was no interaction between dolomite and NPK fertilizer from all treatments.
\end{abstract}

Keywords : Histosol, acidity, liming and fertilizing, growth and yield of okra plants

\section{PENDAHULUAN}

Indonesia memiliki lahan gambut degan luasan 21 juta ha atau $10.8 \%$ dari luas daratan Indonesia. Di Indonesia lahan gambut sebagian besar terdapat di empat pulau besar yaitu di Sumatera 35\%, Kalimantan 32\%, Papua 30\% dan sebagian kecil ada di Sulawesi (Radjagukguk, 1992; 1995). Aceh memiliki lahan gambut \pm 274.051 ha. Penyebarannya di wilayah barat selatan Aceh meliputi; Kabupaten Aceh Selatan seluas 169 ribu ha (61,6 \% dari luas total gambut di propinsi), dan di Kabupaten
Aceh Barat seluas 105 ribu ha $(38,4 \%)$, yang sebagian besar berupa gambut-sedang yaitu sekitar $64,1 \%$ dari total luas wilayah propinsi. Sisanya berupa gambut-dalam dengan luas sekitar $35,1 \%$ dan gambutdangkal dengan luas sekitar 0,8\%. Komposisi gambut-sedang umumnya didominasi oleh Saprists/ Hemists, dan sebagian Hemists/ mineral. Sedangkan gambut-dalam tersusun terbanyak dari Saprists/ Hemists, dan sebagian Hemists/ Saprists. Gambut-dangkal seluruhnya 
merupakan Hemists/ mineral (Wahyunto et al., 2005).

Pengembangan lahan gambut sebagai lahan pertanian terdapat berbagai kendala salah satunya adalah sifat kimia tanah. Permasalahan sifat kimia tanah pada lahan gambut terutama pada tingginya kemasaman tanah sehingga menyebabkan salah satu unsur hara makro ensensial yang dibutuhkan oleh tanaman yaitu $\mathrm{P}$ tidak tersedia meskipun $\mathrm{P}$ total tinggi, akan tetapi P-available bagi tanaman rendah.

Lahan gambut di University Farm Universitas Teuku Umar Aceh Barat memiliki pH 4.3 dengan kriteria penilian sangat masam. Tanah dengan tingkat kemasaman yang tinggi ini akan memunculkan unsur toksik $\mathrm{Fe}$ dan $\mathrm{Al}$, unsur ini mampu menekan ketersediaan unsur $\mathrm{P}(\mathrm{Fe}-\mathrm{P})$ dan (Al-P) sehingga tidak tersedia bagi tanaman. Hasil analisis tanah gambut pada Laboratorium Penelitian Tanah dan Tanaman Universitas Syiah Kuala menunjukan kandungan N, P, dan K dengan kriteria sangat rendah yaitu $1,02 \%$ $\mathrm{N}, 2,30 \mathrm{mg} / \mathrm{kg}^{-1} \mathrm{P}$, dan $\mathrm{K}=0,30 \mathrm{mg} / \mathrm{kg}^{-1}$.

Persebaran lahan gambut yang luas ini membuka peluang untuk dimanfaatkan menjadi lahan pertanian produktif, tentunya akan diarahkan pada lahan gambut dengan tingkat kedalaman yang rendah/ gambut dangkal. Adapun upaya yang dapat dilakukan untuk mengatasi permasalahan pada lahan gambut yaitu dengan pemberian kapur dolomit dan penambahan pupuk majemuk yaitu NPK dengan koefisien keasaman netral, sehingga tanah gambut yang sifatnya asam tidak menambah kemasamannya.

Widodo (2000), menyebutkan bahwa penambahan kapur dolomite 2 - 4 ton/ha mampu menaikan $\mathrm{pH}$ tanah antara 12 level. Selain itu pemberian pupuk NPK ini diberikan dengan tujuan untuk manambah suplai nutrisi yang rendah pada tanah gambut. Karana pada dasarnya ketersediaan unsur hara yang lengkap dan berimbang dan dapat diserap oleh tanaman merupakan faktor yang menentukan dalam pertumbuhan dan produksi tanaman Okra (Nyanjang, 2003). Unsur hara nitrogen (N), fosfor (P), dan kalium (K) merupakan unsur hara makro yang sangat dibutuhkan untuk pertumbuhan tanaman.

Penelitian ini bertujuan untuk melihat pengaruh pemberian dolomit dan pemupukan NPK terhadap pertumbuhan dan hasil Okra (Abelmoschus esculentus L.) pada tanah Histosol.

\section{METODE}

Penelitian ini dilaksanakan di Kebun Percobaan Fakultas Pertanian Universitas Teuku Umar Meulaboh Aceh Barat, dari 01 Desember 2017 sampai dengan 25 Maret 2018. Bahan-bahan yang digunakan dalam penelitian ini meliputi : tanah Histosol yang di ambil pada lahan University Farm Universitas Teuku Umar Kabupaten Aceh Barat. Benih okra varietas hijau, kapur Dolomit dan pupuk NPK Mutiara 16-16-16, polybag ukuran $12 \mathrm{~kg}(40 \times 50 \mathrm{~cm})$, dan Dithane yang diperoleh dari Toko Pertanian Meulaboh. Sedangkan peralatan yang digunakan dalam penelitian ini meliputi: cangkul, parang, pisau, gunting, gembor, alat tulis, timbangan, $\mathrm{pH}$ tancap, jangka sorong, dan meteran.

Penelitian ini menggunakan Rancangan Acak Kelompok (RAK) faktorial $4 \times 4$ dengan 3 ulangan. Faktorfaktor yang diteliti meliputi : 1). Pemberian dolomit (D) terdiri dari 4 taraf yaitu: $\mathrm{D}_{0=}$ Tanpa pemberian pengapuran, $\mathrm{D}_{1}=3$ ton $/ \mathrm{h}$ (22.5 gram/polybag), $\mathrm{D}_{2}=6$ ton $/ \mathrm{h} \quad(45$ gram/polybag), $\quad \mathrm{D}_{3}=9 \mathrm{ton} / \mathrm{h} \quad(67.5$ gram/polybag). 2). Pupuk NPK (N) terdiri dari 4 taraf yaitu: $\mathrm{N}_{0}=$ Tanpa pemberian pupuk NPK, $\mathrm{N}_{1}=150 \mathrm{~kg} / \mathrm{h}$ (11.25 gram/ polybag), $\quad \mathrm{N}_{2}=250 \mathrm{~kg} / \mathrm{h} \quad(18.75 \mathrm{gram} /$ polybag), $\quad \mathrm{N}_{3}=350 \mathrm{~kg} / \mathrm{h}(26.25 \mathrm{gram} /$ polybag). Dengan demikian terdapat 16 kombinasi perlakuan dengan 3 ulangan, 
maka secara keseluruhan terdapat 48 satuan unit percobaan.

Pelaksanaan Penelitian

\section{a. Pengecekan $\mathrm{pH}$}

Tanah gambut di University Farm Universitas Teuku Umar Kabupaten Aceh Barat, terlebih dahulu dilakukan test $\mathrm{pH}$ di lapangan dengan menggunakan $\mathrm{pH}$ meter. Jenis tanah yang digunakan dalam penelitian ini merupakan tanah Histosol level pelapukan sapric (tingkat pelapukan tinggi) hingga hemic (tingkat pelapaukan sedang).

\section{b. Persiapan Media Tanam}

Tanah Histosol yang telah disiapkan dan dikering anginkan, kemudian dimasukkan ke polybag dengan berat 12 $\mathrm{kg} /$ polybag, selanjutnya polybag yang sudah terisi tanah tersebut disusun sesuai dengan bagan percobaan.

c. Penyiapan Pengapuran

Pengapuran diberikan 14 hari sebelum tanam sesuai dengan perlakuan.

\section{d. Penanaman}

Penanaman dilakukan dengan cara membuat lubang tanam kemudian dimasukan 3 benih perlubang tanam. Setelah tanaman tumbuh, maka untuk satu polybag dipertahan satu tanaman okra yang pertumbuhan paling baik, seleksi tanaman sampel umur 14 hari setelah tanam. Dua tanaman dimatikan dan dikembalikan ke dalam polybag dengan tujuan meminimalisir terangkutnya unsur hara. e. Pemberian Pupuk NPK

Pemupukan dilakukan sebelum tanam 7 hari diberikan langsung ke dalam polybag dengan cara ditebar pada bagian atas serta diaduk sampai merata dengan menggunakan tangan, disesuaikan dengan dosis perlakuan.

f.Pemeliharaan

Penyulaman dilakukan satu minggu setelah tanam, benih yang tidak tumbuh diganti dengan benih yang sudah dipersiapkan sebelumnya/bibit cadangan.
Penyiraman dilakukan setiap hari, disiram pada sore hari dan disesuai dengan kondisi cuaca setempat. Penyiangan dilakukan secara manual apabila ada gulma yang tumbuh di sekitar tanaman, bertujuan untuk memperkecil kemungkinan tanaman bersaing dalam hal memperoleh unsur hara dengan gulma. Pengendalian hama dan penyakit tanaman dilakukan dengan menggunakan Dithane dan Dursban.

g. Pemanenan

Pemanenan dilakukan ketika tanaman berumur 90 HST. Buah yang cukup layak dipanen yaitu bewarna hijau sama mulai dari pangkal sampai ujung. Panen dilakukan dengan cara memetik (memotong) tangkai buah dengan gunting agar tidak merusak tanaman.

h. Parameter Pengamatan

Parameter yang diamati pada penelitian ini adalah:

1. Analisis $\mathrm{pH}$

Analisis pH dilakukan 2 kali, analisis awal dilakukan pada tanah yang belum diberikan pengapuran dan analisis kedua dilakukan pada saat dua minggu setelah pengapuran.

2. Tinggi Tanaman $(\mathrm{cm})$

Tinggi tanaman diukur pada umur 15, 30, 45 dan 60 HST. Tinggi tanaman di ukur dari pangkal batang yang telah diberi tanda sampai titik tumbuh tertinggi dengan menggunakan meteran dalam satuan centimeter $(\mathrm{cm})$.

3. Diameter Pangkal Batang (mm)

Diameter pangkal batang diukur pada umur 15, 30, 45 dan 60 HST. Diameter pangkal batang diamati dengan cara mengukur pada pangkal batang dengan menggunakan jangka sorong dalam satuan mili meter (mm).

4. Jumlah Buah Per Tanaman (buah)

Pegamatan jumlah buah dihitung pada saat buah yang sudah dipanen per tanaman pada panen I, II, dan III. 


\section{Berat Buah (gram)}

Berat buah dihitung pada umur panen I, II, dan III dengan cara di timbang per tanaman sampel dengan memakai timbangan analitik dalam satuan gram.

\section{Panjang Buah (cm)}

Pengamatan panjang buah dihitung pada umur panen I, II, dan III HST. Panjang buah diukur pada bagian ujung sampai pangkal buah dengan memakai meteran dalam satuan centimeter $(\mathrm{cm})$.

\section{Diameter Buah (mm)}

Pengamatan diameter buah (mm) pada umur panen I, II, dan III, dengan menggunakan jangka sorong dengan mengukur lingkar buah persis pada bagian tengah buah.

8. Produksi (ton/ha)

Produksi (ton/ha) tanaman Okra dihitung dengan menggunakan rumus sebagai berikut:

Populasi tanaman 1 hektar adalah :

$=\frac{(1000) \mathrm{m}}{(40 \times 40) \mathrm{cm}}=\frac{1000 \mathrm{~m}}{0,16 \mathrm{~m}}=62.500$ tanaman

Selanjutnya; $=B_{2} p \times P t(\mathrm{x} \mathrm{Ha})$

Keterangan:
$\mathrm{B}_{2 \mathrm{p}}=$ berat buah per tanaman

$\mathrm{Pt}=$ populasi tanaman

$\mathrm{x}$ ha $=$ luas lahan dalam hektar

\section{HASIL DAN PEMBAHASAN}

1. Pengaruh Dosis Dolomit $\mathrm{pH}$ tanah

Hasil uji $\mathrm{F}$ pada analisis ragam menunjukkan bahwa $\mathrm{pH}$ tanah berpengaruh sangat nyata terhadap dosis dolomit yang diberikan. Rata-rata $\mathrm{pH}$ dapat dilihat pada Tabel 2. Tabel 2 menunjukan bahwa ratarata analisis $\mathrm{pH}$ tanah yang terbaik dijumpai pada perlakuan dosis dolomit $\left(D_{3}\right)$ yang berbeda nyata dengan perlakuan lainnya. Hal ini di sebabkan karna semakin tinggi dosis dolomit semakin meningkat $\mathrm{pH}$, dikarenakan penambahan $\mathrm{Ca}$ (Kalsium), $\mathrm{Mg}$ (Magnesium) dan terhidrolisis (rumus kimia) sehinga $\mathrm{Fe}$ terputus. Menurut penelitian Surmarwan dan Arman, (2015) semakin tinggi dosis kapur dolomite yang diberikan dan semakin tinggi pula nilai $\mathrm{pH}$. Hanafiah, (2013) peningkatan $\mathrm{pH}$ dapat dilakukan dengan penambahan kapur karbonat dan kalsit $\left(\mathrm{CaCO}_{3}\right)$, jika terhidrolisis akan menghasilkan ion hidroksil penaik $\mathrm{pH}$.

Tabel 2. Rata-rata pengaruh dolomit terhadap $\mathrm{pH}$ tanah pada tanaman okra (Abelmoschus esculentus L.)

\begin{tabular}{lccccc}
\hline \multirow{3}{*}{ Parameter } & \multicolumn{4}{c}{ Dosis Dolomit } & $\begin{array}{r}\text { BNT } \\
0,05\end{array}$ \\
\cline { 2 - 5 } & $\begin{array}{c}\mathrm{D}_{0} \\
(\text { Kontrol })\end{array}$ & $\begin{array}{c}\mathrm{D}_{1} \\
(3 \text { ton } / \mathrm{h})\end{array}$ & $\begin{array}{c}\mathrm{D}_{2} \\
(6 \text { ton } / \mathrm{h})\end{array}$ & $\begin{array}{c}\mathrm{D}_{3} \\
(9 \text { ton } / \mathrm{h})\end{array}$ & \\
\hline \multirow{2}{*}{$\mathrm{pH}$ tanah } & $5,13 \mathrm{a}$ & $5,51 \mathrm{~b}$ & $5,87 \mathrm{~b}$ & $5,93 \mathrm{c}$ & 0,23
\end{tabular}

Ket: Angka yang diikuti oleh huruf yang sama pada baris yang sama tidak berbeda nyata pada taraf $5 \%(\mathrm{Uji}$ BNT 0,05$)$

Tinggi Tanaman

Hasil uji $F$ pada analisis ragam menunjukkan bahwa dosis dolomit berpengaruh sangat nyata terhadap tinggi tanaman okra umur 15, 30, 45 dan 60 HST. Rata-rata tinggi tanaman dapat dilihat pada Tabel 3. 
Tabel 3. Rata-rata pengaruh dosis dolomit terhadap tinggi tanaman okra (Abelmoschus esculentus L.)

\begin{tabular}{ccccccc}
\hline \multirow{2}{*}{ Parameter } & \multicolumn{4}{c}{ Dosis Dolomit } & \multirow{3}{*}{$\begin{array}{c}\text { BNT } \\
0,05\end{array}$} \\
\cline { 3 - 6 } & & $\begin{array}{c}\mathrm{D}_{0} \\
(\text { Kontrol })\end{array}$ & $\begin{array}{c}\mathrm{D}_{1} \\
(3 \mathrm{t} \text { ton } / \mathrm{h})\end{array}$ & $\begin{array}{c}\mathrm{D}_{2} \\
(6 \text { ton } / \mathrm{h})\end{array}$ & $\begin{array}{c}\mathrm{D}_{3} \\
(9 \mathrm{ton} / \mathrm{h})\end{array}$ \\
\hline \multirow{2}{*}{ Tinggi } & $15 \mathrm{HST}$ & $4,58 \mathrm{a}$ & $7,53 \mathrm{~b}$ & $7,19 \mathrm{~b}$ & $9,14 \mathrm{c}$ & 1,14 \\
Tanaman & $30 \mathrm{HST}$ & $7,5 \mathrm{a}$ & $15,81 \mathrm{~b}$ & $15,39 \mathrm{~b}$ & $19,04 \mathrm{c}$ & 2,82 \\
$(\mathrm{~cm})$ & $45 \mathrm{HST}$ & $12,47 \mathrm{a}$ & $37,06 \mathrm{~b}$ & $34,67 \mathrm{~b}$ & $45,15 \mathrm{c}$ & 7,24 \\
& $60 \mathrm{HST}$ & $18,25 \mathrm{a}$ & $56,83 \mathrm{~b}$ & $56,44 \mathrm{~b}$ & $69,33 \mathrm{c}$ & 11,88 \\
\hline
\end{tabular}

Ket : Angka yang diikuti oleh huruf yang sama pada baris yang sama tidak berbeda nyata pada taraf $5 \%\left(\mathrm{Uji}_{\mathrm{BNT}} 0,05\right)$

Tabel 3 menunjukan bahwa tinggi tanaman okra umur 15, 30, 45 dan 60 HST yang terbaik dijumpai pada dosis dolomit 9 ton/h $\left(\mathrm{D}_{3}\right)$, berbeda nyata dengan dosis dolomit 3 ton $/ \mathrm{h}\left(\mathrm{D}_{1}\right), 6$ ton/h $\left(\mathrm{D}_{2}\right)$ dan kontrol $\left(\mathrm{D}_{0}\right)$. Hal ini diduga bahwa dengan pemberian dosis dolomit 9 ton/h $\left(\mathrm{D}_{3}\right)$ dapat meningkatnya $\mathrm{pH}$ tanah menjadi netral (56). Dolomit mengandung unsur $\mathrm{Ca}$ dan $\mathrm{Mg}$, menurut Rukmana et al, (1996) dalam Muhammadd et al. (2015) pengapuran mampu meningkatkan $\mathrm{pH}$ tanah, menambah unsur $\mathrm{Ca}, \mathrm{Mg}$ dan ketersediaan unsur $\mathrm{P}$ maupun Mo, mengurangi keracunan unsur $\mathrm{Fe}, \mathrm{Mn}$, Al dan memperbaiki kehidupan mikroorganisme dalam tanah. Rosmarkan et al. (2002), dalam Muhammad et al. (2015) menyatakan, bahwa unsur $\mathrm{Ca}$ berperan dalam pembentukan apikal dan juga pembelahan sel. Sehingga pemberian dolomit yang tepat mampu meningkatakan tinggi tanaman okra.

Diameter Batang (mm)

Hasil uji $F$ pada analisis ragam menunjukkan bahwa dosis dolomit berpengaruh sangat nyata terhadap diameter batang okra umur 15, 30, 45 dan 60 HST. Rata-rata diameter batang dapat dilihat pada Tabel 4.

Tabel 4. Rata-rata pengaruh dosis dolomit terhadap diameter batang okra (Abelmoschus esculentus L.)

\begin{tabular}{|c|c|c|c|c|c|c|}
\hline \multirow{2}{*}{\multicolumn{2}{|c|}{ Parameter }} & \multicolumn{4}{|c|}{ Dosis Dolomit } & \multirow[t]{2}{*}{$\begin{array}{r}\text { BNT } \\
0,05\end{array}$} \\
\hline & & $\begin{array}{c}\mathrm{D}_{0} \\
\text { (Kontrol) }\end{array}$ & $\begin{array}{c}D_{1} \\
\text { (3 ton } / \mathrm{h})\end{array}$ & $\begin{array}{c}\mathrm{D}_{2} \\
\text { (6 ton } / \mathrm{h})\end{array}$ & $\begin{array}{c}\mathrm{D}_{3} \\
(9 \text { ton } / \mathrm{h})\end{array}$ & \\
\hline \multirow{4}{*}{$\begin{array}{c}\text { Diameter } \\
\text { Batang } \\
(\mathrm{mm})\end{array}$} & $15 \mathrm{HST}$ & $2,58 \mathrm{a}$ & $4,80 \mathrm{bc}$ & $4,64 \mathrm{bc}$ & $5,47 \mathrm{c}$ & 0,53 \\
\hline & $30 \mathrm{HST}$ & $3,35 \mathrm{a}$ & $5,70 \mathrm{bc}$ & $5,63 \mathrm{c}$ & $6,69 \mathrm{c}$ & 1,00 \\
\hline & $45 \mathrm{HST}$ & $3,50 \mathrm{a}$ & $8,33 \mathrm{~b}$ & $8,72 b c$ & $10,19 \mathrm{c}$ & 1,30 \\
\hline & $60 \mathrm{HST}$ & $4,36 \mathrm{a}$ & $10,36 \mathrm{~b}$ & $10,61 \mathrm{~b}$ & $11,82 \mathrm{~b}$ & 1,56 \\
\hline
\end{tabular}

Tabel 4 menujukan bahwa diameter batang okra umur 15, 30 dan 45 HST yang terbaik dijumpai pada dosis dolomit dosis dolomit 9 ton/ha $\left(D_{3}\right)$, yang tidak berbeda nyata dengan dosis dolomit 3 ton/ha $\left(\mathrm{D}_{1}\right)$ dosis dolomit, 6 ton/ha $\left(\mathrm{D}_{2}\right)$, namun berbeda nyata dengan kontrol $\left(\mathrm{D}_{0}\right)$. Hal ini dikarenakan pemberian dolomit 9 ton/ha 
$\left(\mathrm{D}_{3}\right)$ ke dalam tanah dapat meningkatkan $\mathrm{pH}$ tanah. Peningkatan ini terjadi disebabkan oleh adanya gugus ion-ion hidroksil yang mengikat kation-kation asam $(\mathrm{H}$ dan $\mathrm{Al})$ pada koloid tanah menjadi inaktif, sehingga pH meningkat. Kapur dolomit mengurangi keasaman tanah $(\mathrm{pH})$ bergerak meningkat oleh perubahan beberapa $\mathrm{H}^{+}$menjadi air. Sesuai pendapat (Nurhayati, 2013) yang menerangkan bahwa $\mathrm{pH}$ netral (5-7) mengakibatkan mikroorganisme perombak bahan organik tanah dan penambat $\mathrm{N}$ dapat bekerja secara optimal didalam tanah sehingga dapat mempengaruhi diameter pangkal batang.

Jumlah Daun

Hasil uji $F$ pada analisis ragam menunjukkan bahwa dosis dolomit berpengaruh sangat nyata terhadap jumlah daun okra umur 15, 30, 45 dan 60 HST. Rata-rata jumlah daun dapat dilihat pada Tabel 5.

Tabel 5. Rata-rata pengaruh dosis dolomit terhadap jumlah daun okra (Abelmoschus esculentus L.)

\begin{tabular}{|c|c|c|c|c|c|c|}
\hline \multirow{2}{*}{\multicolumn{2}{|c|}{ Parameter }} & \multicolumn{4}{|c|}{ Dosis Dolomit } & \multirow{2}{*}{$\begin{array}{l}\text { BNT } \\
0,05\end{array}$} \\
\hline & & $\begin{array}{c}\mathrm{D}_{0} \\
\text { (Kontrol) }\end{array}$ & \multirow{2}{*}{$\begin{array}{c}\mathrm{D}_{\mathrm{l}} \\
(3 \text { ton } / \mathrm{h}) \\
4,31 \mathrm{~b}\end{array}$} & \multirow{2}{*}{$\begin{array}{c}\mathrm{D}_{2} \\
(6 \text { ton } / \mathrm{h}) \\
4,40 \mathrm{c}\end{array}$} & $\begin{array}{c}\mathrm{D}_{3} \\
(9 \text { ton } / \mathrm{h})\end{array}$ & \\
\hline & $15 \mathrm{HST}$ & $3,28 \mathrm{a}$ & & & $4,92 \mathrm{c}$ & 0,54 \\
\hline & $30 \mathrm{HST}$ & $3,44 \mathrm{a}$ & $6,75 \mathrm{~b}$ & $6,50 \mathrm{~b}$ & $6,94 \mathrm{~b}$ & 0,97 \\
\hline \multirow[t]{2}{*}{ Daun } & $45 \mathrm{HST}$ & $3,64 \mathrm{a}$ & $8,56 \mathrm{c}$ & $8,14 \mathrm{c}$ & $9,28 \mathrm{c}$ & 1,14 \\
\hline & $60 \mathrm{HST}$ & $3,28 \mathrm{a}$ & $7,72 \mathrm{~b}$ & $8,39 \mathrm{~b}$ & $8,64 \mathrm{~b}$ & 1,34 \\
\hline
\end{tabular}

Ket : Angka yang diikuti oleh huruf yang sama pada baris yang sama tidak berbeda nyata pada taraf $5 \%$ (Uji BNT 0,05 )

Tabel 5 menujukan bahwa jumlah daun yang terbanyak dijumpai pada umur 15 dan 45 HST dengan dosis dolomit 9 ton/ha $\left(\mathrm{D}_{3}\right)$ tidak berbeda nyata dengan dosis dolomit 3 ton/ha $\left(\mathrm{D}_{1}\right)$ dan 6 ton/ha $\left(\mathrm{D}_{2}\right)$. Pada umur 30 dan 60 HST pada dosis dolomit 3 ton/h $\left(\mathrm{D}_{1}\right), 6$ ton/h $\left(\mathrm{D}_{2}\right)$, dan 9 ton/h $\left(\mathrm{D}_{3}\right)$ tidak berbeda nyata, namun berbeda nyata dengan dosis dolomit 0 ton $/ \mathrm{h}$ $\left(\mathrm{D}_{0}\right)$. Hal ini diduga dosis dolomit 9 ton/ha $\left(\mathrm{D}_{3}\right)$ dapat meningkatkan $\mathrm{pH}$ tanah, sehingga dapat memacu aktivitas mikroorganisme tanah yang berperan dalam dekomposisi bahan organik tanah, sehingga mengakibatkan terjadinya peningkatan pertumbuhan vegetatif tanaman salah satunya adalah jumlah daun. Menurut Nyakpa (1988) dalam Nurhayati (2011), bahwa kapur dolomit mengandung unsur $\mathrm{Ca}$ dan $\mathrm{Mg}$, dimana kedua jenis unsur ini melalui reaksi hidrolisis dapat melepaskan ion $\mathrm{OH}-$ yang berpengaruh terhadap peningkatan $\mathrm{pH}$ tanah.

Pemberian kapur dolomit pada tanah gambut selain dapat menaikkan $\mathrm{pH}$ tanah, juga meningkatkan ketersediaan $\mathrm{P}, \mathrm{K}$ dan $\mathrm{Mg}$ tukar sehingga dapat meningkatkan pertumbuhan tanaman. Sedangkan menurut Hasibuan (1999) dalam Prayitno (2015), peningkatan pertumbuhan vegetatif tanaman yang diberi kapur karena adanya perbaikan penyediaan hara bagi tanaman.

Pemanenan umur 73 HST

Hasil uji $\mathrm{F}$ pada analisis ragam menunjukkan bahwa dosis dolomit berpengaruh sangat nyata terhadap panjang buah okra umur 73 HST dan berpengaruh 
nyata terhadap berat buah umur 73 HST, namun berpengaruh tidak nyata terhadap diameter buah, jumlah buah umur dan produksi per hektar (ton) 73 HST. Rata-rata panjang buah, diameter buah, jumlah buah, dan berat buah dapat dilihat pada Tabel 6 .

Tabel 6. Rata-rata pengaruh dosis dolomit terhadap panjang buab. diameter buah, jumlah buah, berat buah dan produksi perhektar (ton) okra (Abelmoscinus esculentus I..)

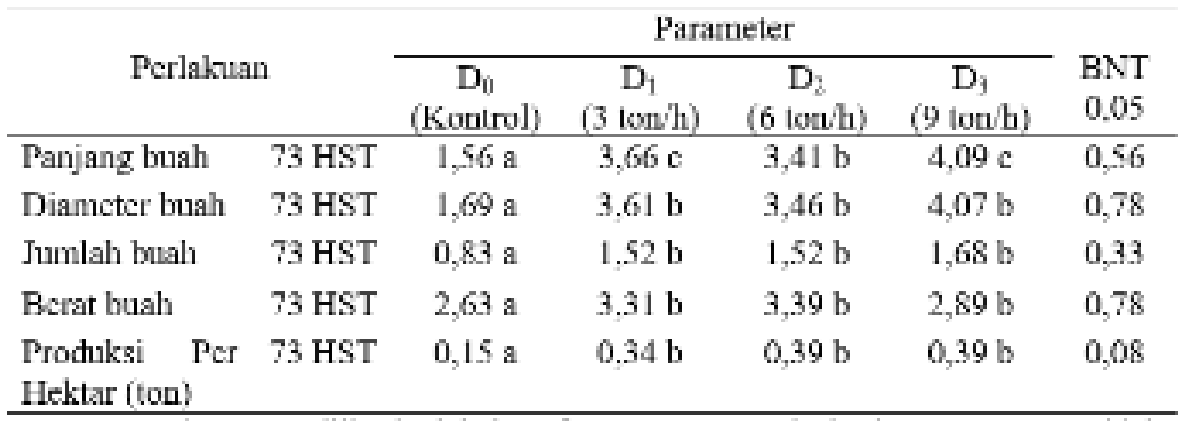

Ket: Angka yang diikuti oleh huruf yang sama pada baris yane sama tidak berbeda nyata pada taraf $5 \%$ (Uji BNT 0,05 )

Tabel 6 menujukan bahwa panjang buah yang terbaik dijumpai pada dosis dolomit 9 ton/ha $\left(\mathrm{D}_{3}\right)$, yang tidak berbeda nyata dengan perlakuan dosis dolomit 3 ton/h $\left(\mathrm{D}_{1}\right)$. Namun berbeda nyata dengan dosis dolomit 6 ton/ha $\left(\mathrm{D}_{2}\right)$ dan kontrol $\left(\mathrm{D}_{0}\right)$. Hal ini diduga bahwa dengan meningkatnya ketersediaan $\mathrm{Ca}$ dan $\mathrm{Mg}$ di dalam tanah oleh pupuk dolomit sehingga dapat memacu turgor sel dan pembentukan klorofil sehingga proses fotosintesis menjadi meningkat dan produk dari fotosintesis juga meningkat. Selain itu, pupuk dolomit ini mengandung unsur $\mathrm{Mg}$ yang dapat mengatur serapan unsur hara lain seperti dapat menambah ketersediaan unsur $\mathrm{P}$ yang dimana unsur ini berperan dalam pembentukan ATP. ATP ini digunakan sebagai sumber energi dalam asimilasi karbondioksida menjadi gula selama fotosintesis. Gula hasil fotosintesis ini akan ditransportasikan ke organ tanaman untuk digunakan dalam pertumbuhan atau disimpan oleh tanaman. Dengan demikian unsur $\mathrm{Ca}$ dan $\mathrm{Mg}$ mempunyai peranan penting dalam membantu proses fotosintesis dalam menghasilkan karbohidrat yang berperan dalam pembentukan panjang okra (Soepardi,1983 ; dalam Setiawan, 2008).
Diameter buah tidak berbeda nyata dengan dosis dolomit 9 ton/ha $\left(\mathrm{D}_{3}\right), 6$ ton/h $\left(\mathrm{D}_{2}\right)$, dan 3 ton/h $\left(\mathrm{D}_{1}\right)$. Namun berbeda nyata dengan kontrol $\left(\mathrm{D}_{0}\right)$. Hal ini diduga bahwa pada tanah gambut yang di berikan dolomit tidak memberikan hasil yang bagus pada diameter buah. Hal ini sejalan dengan pendapat Hakim et al. (1986) dalam Muhammad et al. (2015) yang menyatakan bahwa tanah gambut umumnya ketersediaan unsur Al larut lebih dominan sehingga cenderung mengikat ketersediaan unsur hara $\mathrm{P}$, sehingga menghabat pertumbuhan buah.

Jumlah buah dengan dosis dolomit 9 ton/ha $\left(\mathrm{D}_{3}\right)$ tidak berbeda nyata dengan perlakuan dosis dolomit 3 ton/h $\left(\mathrm{D}_{1}\right)$ dan 6 ton/h $\left(\mathrm{D}_{2}\right)$. Namun berbeda nyata dengan kontrol $\left(\mathrm{D}_{0}\right)$. Hal ini sebabkan karena dolomit yang mengandung kadar $\mathrm{Ca}$ dan $\mathrm{Mg}$ dalam tanah merupakan unsur yang sangat diperlukan dalam sintesis klorofil untuk menentukan berlangsungnya proses fotosintesis. Proses fotosintesis yang optimal sangat diperlukan dalam proses pertumbuhan tanaman terutama pada fase pembentukan buah, sehingga menentukan hasil dari tanaman. Mg berfungsi sebagai pembentuk klorofil dan karbohidrat dan 
dapat berfungsi sebagai aktifator dalam proses fotosintesis, sedangkan unsur $\mathrm{Ca}$ berfungsi mempergiat pembelahan sel meristem dan menambah organ tanaman seperti jumlah buah (Kuswandi, 2005).

Berat buah dengan dosis dolomit 9 ton/ha $\left(\mathrm{D}_{3}\right)$ tidak berbeda nyata dengan perlakuan dosis dolomit 3 ton $/ \mathrm{h}\left(\mathrm{D}_{1}\right)$ dan 6 ton/h $\left(\mathrm{D}_{2}\right)$. Namun berbeda nyata dengan kontrol $\left(\mathrm{D}_{0}\right)$. Produksi per hektar (ton) hasil tanaman okra dengan dosis dolomit 9 ton/ha $\left(D_{3}\right)$ tidak berbeda nyata dengan perlakuan dosis dolomit 3 ton/h $\left(\mathrm{D}_{1}\right)$ dan 6 ton/h $\left(\mathrm{D}_{2}\right)$. Namun berbeda nyata dengan kontrol $\left(\mathrm{D}_{0}\right)$. Hal ini diduga bahwa peningkatan pertumbuhan dan hasil produksi tanaman sangat dipengaruhi oleh adanya peranan unsur hara yang terkandung didalam dolomit seperti unsur hara $\mathrm{N}, \mathrm{P}, \mathrm{K}, \mathrm{Ca}$ dan Mg. Lingga dan Marsono (2008) dalam Prayitno (2015) menjelaskan bahwa peranan nitrogen bagi tanaman adalah untuk merangsang pertumbuhan secara keseluruhan, khususnya cabang, batang dan daun. Nitrogen berfungsi sebagai pembentuk klorofil, protein dan lemak. Nitrogen juga sebagai penyusun enzim yang terdapat dalam sel, sehingga mempengaruhi pembentukan karbohidrat yang sangat berperan dalam pertumbuhan tanaman. Sosrosoedjirdjo (2004) dalam Prayitno (2015) menambahkan bahwa karbohidrat merupakan bahan yang sangat diperlukan dalam pembelahan sel, perpanjangan sel, pembesaran sel dan pembentukan jaringan untuk perkembangan batang, daun, buah dan akar. Fospor berfungsi mengatasai pengaruh negatif dari pemberian nitrogen, memperbaiki perkembangan akar dan memperbaiki kwalitas hasil. Sedangkan kalium berfungsi untuk mengatur berbagai mekanisme metabolik seperti fotosintesa, translokasi karbohidrat, sintesa protein, sehingga meningkatkan ketahanan tanaman dan ketersediaan hasil produksi tanaman yang meningat serta tahan terhadap penyakit dan mengatur keseimbangan nitrogen dan phospor.

Buah menjadi organ yang dominan sebagai tempat penyimpanan karbohidrat, semakin tinggi proses fotosintesis maka semakin besar kandungan karbohidrat yang terdapat pada berat buah, penyerapan hara dan fotosintesis berjalan dengan baik sehingga fotosintat yang terakumulasi juga ikut meningkat protein dan lemak akan berdampak terhadap pembentukan buah (Goldsworthy dan Fisher, 2002 ; dalam Maftuah et al., 2013).

\section{Pengaruh NPK}

$\mathrm{pH}$ tanah

Hasil uji $F$ pada analisis ragam menunjukkan bahwa $\mathrm{pH}$ tanah berpengaruh sangat nyata terhadap NPK yang diberikan. Rata-rata pH dapat dilihat pada Tabel 7.

Tabel 7. Rata-rata pengaruh NPK terhadap $\mathrm{pH}$ tanah pada tanaman okra (Abelmoschus esculentus L.)

\begin{tabular}{lccccc}
\hline \multirow{2}{*}{ Parameter } & \multicolumn{4}{c}{ Dosis NPK } & \multirow{2}{*}{$\begin{array}{c}\text { BNT } \\
0,05\end{array}$} \\
\cline { 2 - 4 } & $\begin{array}{c}\mathrm{N}_{0} \\
\text { Kontrol }\end{array}$ & $\begin{array}{c}\mathrm{N}_{1} \\
150 \mathrm{~kg} / \mathrm{h}\end{array}$ & $\begin{array}{c}\mathrm{N}_{2} \\
250 \mathrm{~kg} / \mathrm{h}\end{array}$ & $\begin{array}{c}\mathrm{N}_{3} \\
350 \mathrm{~kg} / \mathrm{h}\end{array}$ \\
\hline \multirow{2}{*}{$\mathrm{pH}$ tanah } & 5,66 & 5,47 & 5,57 & 5,53 & 0,23 \\
\hline Ket : & $\begin{array}{l}\text { Angka yang diikuti oleh huruf yang sama pada baris yang sama } \\
\text { berbeda nyata pada taraf 5\% (Uji BNT 0,05). }\end{array}$ & tidak
\end{tabular}


Tabel 7 menunjukan bahwa rata-rata analisis $\mathrm{pH}$ tanah pada dosis NPK tidak berbeda nyata pada semua perlakuan. Hal ini di sebabkan karena penambahan NPK yang diberikan pada tanah gambut tidak memberikan peningkatan $\mathrm{pH}$ tanah. Pupuk NPK dapat menurunkan $\mathrm{pH}$ tanah, karena $10 \%$ Sataun yang dikandung oleh pupuk ini akan bereaksi dengan molekul air, oksigen, dan $\mathrm{CO}_{2}$ di dalam tanah akan menghasilkan ion sulfat dan sejumlah ion $\mathrm{H}^{+}$. Hal ini juga diperjelas oleh Starast et al. (2003) dalam Elizabeth (2014) menyatakan bahwa pemupukan menggunakan pupuk majemuk
NPK dapat menurunkan $\mathrm{pH}$ tanah karena pupuk ini mengandung sulfur dan ammonium yang akan terhidrolisis menghasilkan ion $\mathrm{H}^{+}$yang menyebabkan $\mathrm{pH}$ tanah menurun.

Tinggi Tanaman

Hasil uji $F$ pada analisis ragam menunjukkan bahwa dosis NPK berpengaruh sangat nyata terhadap tinggi tanaman okra umur 15, 30, 45 dan 60 HST. Rata-rata parameter tinggi tanaman dapat dilihat pada Tabel 8.

Tabe1 8. Rata-rata pengaruh dosis NPK terhadap tinggi tanaman okra (Abelmoschus esculentus L.)

\begin{tabular}{ccccccc}
\hline \multirow{2}{*}{ Parameter } & \multicolumn{4}{c}{ Dosis NPK } & BNT \\
\cline { 3 - 6 } & & $\mathrm{N}_{0}$ & $\mathrm{~N}_{1}$ & $\mathrm{~N}_{2}$ & $\mathrm{~N}_{3}$ & \\
& & Kontrol & $150 \mathrm{~kg} / \mathrm{h}$ & $250 \mathrm{~kg} / \mathrm{h}$ & $350 \mathrm{~kg} / \mathrm{h}$ & \\
\hline \multirow{2}{*}{ Tinggi } & $15 \mathrm{HST}$ & $5,29 \mathrm{a}$ & $7,58 \mathrm{~b}$ & $8,19 \mathrm{~b}$ & $7,37 \mathrm{~b}$ & 1,14 \\
Tanaman & $30 \mathrm{HST}$ & $8,46 \mathrm{a}$ & $16,15 \mathrm{~b}$ & $17,88 \mathrm{c}$ & $15,25 \mathrm{~b}$ & 2,82 \\
$(\mathrm{~cm})$ & $45 \mathrm{HST}$ & $18,92 \mathrm{a}$ & $36,54 \mathrm{c}$ & $40,83 \mathrm{c}$ & $33,06 \mathrm{bc}$ & 7,24 \\
& $60 \mathrm{HST}$ & $31,00 \mathrm{a}$ & $56,81 \mathrm{~b}$ & $62,72 \mathrm{~b}$ & $50,33 \mathrm{~b}$ & 11,88 \\
\hline
\end{tabular}

Ket: Angka yang diikuti oleh huruf yang sama pada baris yang sama tidak berbeda nyata pada taraf $5 \%$ (Uji BNT 0,05$)$

Tabel 8 menujukan bahwa tinggi tanaman okra yang terbaik dijumpai pada umur $30 \mathrm{HST}$ dengan dosis NPK $250 \mathrm{~kg} / \mathrm{h}$ $\left(\mathrm{N}_{2}\right)$, yang berbeda nyata dengan perlakuan lainnya. Umur 15 dan 60 HST tinggi tanaman dengan dosis NPK $150 \mathrm{~kg} / \mathrm{h}\left(\mathrm{N}_{1}\right)$, NPK $250 \mathrm{~kg} / \mathrm{h}\left(\mathrm{N}_{2}\right)$, dan NPK $350 \mathrm{~kg} / \mathrm{h}\left(\mathrm{N}_{3}\right)$ tidak berbeda nyata, namun berbeda nyata dengan kontrol $\left(\mathrm{N}_{0}\right)$. Umur 45 HST tinggi tanaman dengan dosis NPK $150 \mathrm{~kg} / \mathrm{h}\left(\mathrm{N}_{1}\right)$, NPK $250 \mathrm{~kg} / \mathrm{h}\left(\mathrm{N}_{2}\right)$, dan NPK $350 \mathrm{~kg} / \mathrm{h}\left(\mathrm{N}_{3}\right)$ tidak berbeda nyata. Namun, berbeda nyata dengan kontrol $\left(\mathrm{N}_{0}\right)$ Hal ini diduga bahwa pemberian pupuk NPK pada dosis ini memiliki unsur hara yang dibutuhkan pada tanaman dapat mendukung pertumbuhan dan pertambahan tinggi tanaman yang dibutuhkan oleh tanaman okra. Hal ini sejalan dengan pendapat Sarwono (1995) dalam Firmansyah et al. (2016) menyatakan bahwa NPK merupakan pupuk majemuk, serta mengandung unsur mikro $\mathrm{Bo}, \mathrm{Cu}$, dan Mn yang merupakan unsur hara makro dan siap diserap tanaman. Selain itu pupuk majemuk NPK melepaskan unsur-unsur hara secara bertahap sehingga dapat diserap tanaman sesuai kebutuhan tanaman. Tanaman okra membutuhkan nitrogen, fosfor, dan kalium dalam jumlah yang relatif banyak, oleh karena itu ketiga unsur hara tersebut harus tersedia bagi tanaman untuk menunjang pertumbuhan pada tinggi tanaman okra.

Diameter Batang (mm)

Hasil uji $F$ pada analisis ragam menunjukkan bahwa dosis NPK berpengaruh sangat nyata terhadap diameter 
batang okra umur 15, 30, 45 dan 60 HST. Rata-rata parameter diameter batang dapat dilihat pada Tabel 9.

Tabel 9 menujukan bahwa diameter batang okra pada umur 15 HST dengan dosis NPK $150 \mathrm{~kg} / \mathrm{h}\left(\mathrm{N}_{1}\right)$ tidak berbeda nyata dengan dengan dosis NPK $250 \mathrm{~kg} / \mathrm{h}$ $\left(\mathrm{N}_{2}\right)$ dan $350 \mathrm{~kg} / \mathrm{h}\left(\mathrm{N}_{3}\right)$. Namun, berbeda nyata dengan kontrol $\left(\mathrm{N}_{0}\right)$. Umur 30 dan 45 HST dosis NPK $150 \mathrm{~kg} / \mathrm{h}\left(\mathrm{N}_{1}\right), 250 \mathrm{~kg} / \mathrm{h}$ $\left(\mathrm{N}_{2}\right)$ dan $350 \mathrm{~kg} / \mathrm{h}\left(\mathrm{N}_{3}\right)$ tidak berbeda nyata. Namun, berbeda nyata dengan kontrol $\left(\mathrm{N}_{0}\right)$. Umur 60 HST diameter batang yang terbaik dijumpai pada dosis NPK $250 \mathrm{~kg} / \mathrm{h}\left(\mathrm{N}_{2}\right)$ yang tidak berbeda nyata dengan dosis NPK $150 \mathrm{~kg} / \mathrm{h}\left(\mathrm{N}_{1}\right)$. Namun, berbeda nyata dengan dosis NPK $350 \mathrm{~kg} / \mathrm{h}\left(\mathrm{N}_{3}\right)$ dan kontrol $\left(\mathrm{N}_{0}\right)$. Hal ini dikarenakan pembesaran pada diameter batang tanaman okra dipengaruhi oleh dosis $\mathrm{K}$ dan $\mathrm{P}$. Pemupukan $\mathrm{K}$ dan $\mathrm{P}$ dapat meningkatkan pertumbuhan vegetatif tanaman. Peningkatan ini disebabkan nutrisi dan hara yang dibutuhkan tanaman berada dalam jumlah yang cukup memadai untuk di serap oleh tanaman dan dapat menunjang kebutuhan vegetatif tanaman (Hilman 1994).

Tabe19. Rata-rata pengaruh dosis NPK terhadap diameter batang okra (Abelmoschus esculentus L.)

\begin{tabular}{|c|c|c|c|c|c|c|}
\hline \multirow{2}{*}{\multicolumn{2}{|c|}{ Parameter }} & \multicolumn{4}{|c|}{ Dosis NPK } & \multirow[t]{3}{*}{$\begin{array}{l}\text { BNT } \\
0,05\end{array}$} \\
\hline & & \multirow{2}{*}{$\begin{array}{c}\begin{array}{c}\mathrm{N}_{0} \\
\text { Kontrol }\end{array} \\
2,97 \mathrm{a}\end{array}$} & \multirow{2}{*}{$\begin{array}{c}\mathrm{N}_{1} \\
150 \mathrm{~kg} / \mathrm{h}\end{array}$} & \multirow{2}{*}{$\begin{array}{c}\mathrm{N}_{2} \\
250 \mathrm{~kg} / \mathrm{h}\end{array}$} & \multirow{2}{*}{$\begin{array}{c}\mathrm{N}_{3} \\
350 \mathrm{~kg} / \mathrm{h} \\
4,51 \mathrm{bc}\end{array}$} & \\
\hline \multirow{4}{*}{$\begin{array}{c}\text { Diameter } \\
\text { Batang } \\
(\mathrm{mm})\end{array}$} & $15 \mathrm{HST}$ & & & & & \\
\hline & $30 \mathrm{HST}$ & $3,74 \mathrm{a}$ & $5,58 \mathrm{~b}$ & $6,38 \mathrm{~b}$ & $5,42 \mathrm{~b}$ & 1,00 \\
\hline & $45 \mathrm{HST}$ & $5,02 \mathrm{a}$ & $8,23 \mathrm{~b}$ & $9,37 \mathrm{~b}$ & $8,11 \mathrm{~b}$ & 1,30 \\
\hline & $60 \mathrm{HST}$ & $6,76 \mathrm{a}$ & $9,71 b c$ & $11,07 \mathrm{c}$ & $9,61 \mathrm{~b}$ & 1,56 \\
\hline
\end{tabular}

Ket: Angka yang diikuti oleh huruf yang sama pada baris yang sama tidak berbeda nyata pada taraf $5 \%$ (Uji BNT 0,05$)$.

Unsur hara NPK berfungsi dalam pertumbuhan tanaman, sebagai komponen molekul enzim dan molekul klorofil, yang berperan dalam proses transfer energi di dalam sel dan dalam proses perombakan fotosintat menjadi molekul sederhana yang disusun kembali menjadi molekul bahan lain yang dikehendaki pada proses metabolisme sel tanaman (Spiertz \& Ellen 1999; dalam Firmansyah, 2016).
Jumlah Daun

Hasil uji $\mathrm{F}$ pada analisis ragam menunjukkan bahwa dosis NPK berpengaruh sangat nyata terhadap jumlah daun okra umur 15 dan 30 HST dan berpengaruh tidak nyata pada umur 45 dan 60 HST. Rata-rata parameter jumlah daun dapat dilihat pada Tabel 10. 
Tabel 10. Rata-rata pengaruh dosis NPK terhadap jumlah daun okra (Abelmoschus esculentus L.)

\begin{tabular}{|c|c|c|c|c|c|c|}
\hline \multirow{2}{*}{\multicolumn{2}{|c|}{ Parameter }} & \multicolumn{4}{|c|}{ Dosis NPK } & \multirow[t]{2}{*}{$\begin{array}{l}\text { BNT } \\
0,05\end{array}$} \\
\hline & & \multirow{2}{*}{$\begin{array}{c}\mathrm{N}_{0} \\
\text { Kontrol } \\
3.64 \mathrm{a}\end{array}$} & \multirow{2}{*}{$\begin{array}{c}\mathrm{N}_{1} \\
150 \mathrm{~kg} / \mathrm{h} \\
4,25 \mathrm{~b}\end{array}$} & \multirow{2}{*}{$\begin{array}{c}\mathrm{N}_{2} \\
250 \mathrm{~kg} / \mathrm{h}\end{array}$} & $\begin{array}{c}\mathrm{N}_{3} \\
350 \mathrm{~kg} / \mathrm{h}\end{array}$ & \\
\hline & $15 \mathrm{HST}$ & & & & $430 \mathrm{~h}$ & 0.54 \\
\hline Jumlah & 30 HST & $4,50 \mathrm{a}$ & $6,53 \mathrm{~b}$ & $6,44 b$ & $6,17 b$ & 0.97 \\
\hline \multirow[t]{2}{*}{ Daun } & 45 HST & 7,06 & 7,19 & 7,78 & 7,58 & - \\
\hline & $60 \mathrm{HST}$ & 7,92 & 6,50 & 7,36 & 6,25 & - \\
\hline
\end{tabular}

Tabel 10 menujukan bahwa jumlah daun pada umur 15 dan 30 HST tidak berbeda nyata dengan dosis NPK $350 \mathrm{~kg} / \mathrm{h}$ $\left(\mathrm{N}_{3}\right), 250 \mathrm{~kg} / \mathrm{h}\left(\mathrm{N}_{2}\right), 150 \mathrm{~kg} / \mathrm{h}\left(\mathrm{N}_{1}\right)$. Namun, berbeda nyata dengan kontrol $\left(\mathrm{N}_{0}\right)$. Hal ini diduga bahwa unsur $\mathrm{N}, \mathrm{P}$, dan $\mathrm{K}$ sangat mempengaruhi pertumbuhan jumlah daun. Wibisono dan Basri (1993) dalam Putra et al, (2012) menyatakan bahwa tanaman dapat tumbuh dan berproduksi dengan sempurna bila unsur hara yang diperlukan mencukupi. Unsur hara sangat diperlukan oleh tanaman untuk membentuk suatu senyawa yang diperlukan untuk pertumbuhan tanaman melalui pembelahan dan pembesaran sel. Unsur hara yang berperan besar dalam pertumbuhan da perkembangan daun yaitu nitrogen.

Hakim et al. (1986) dalam Putra et al. (2012) mengatakan bahwa nitogen diperlukan untuk memproduksi protein dan bahan-bahan penting lainnya yang dimanfatkan untuk membentuk sel-sel serta klorofil. Klorofil yang tersedia dalam jumlah yang cukup pada daun tanaman akan meningkatkan kemampuan daun untuk menyerap cahaya matahari, sehingga proses fotosintesis akan berjalan lancar.

Pemanenan umur 73 HST

Hasil uji $F$ pada analisis ragam menunjukkan bahwa dosis NPK berpengaruh sangat nyata terhadap panjang buah dan diameter buah okra umur 73 HST. Berpengaruh tidak nyata terhadap jumlah buah, berat buah dan produksi perhektar (ton) okra umur 73 HST. Rata-rata panjang buah, diameter buah, jumlah buah, berat buah dan produksi perhektar (ton) dapat dilihat pada Tabel 11.

Tabel 11. Rata-rata pengaruh dosis NPK terhadap panjang buah, diameter buah, jumlah buah, berat buah dan produksi perhektar (ton) okra (Abelmoschus esculentus L.)

\begin{tabular}{|c|c|c|c|c|c|c|c|}
\hline \multirow{2}{*}{\multicolumn{2}{|c|}{ Perlakuan }} & \multirow[b]{2}{*}{ HST } & \multicolumn{4}{|c|}{ Parameter } & \multirow{2}{*}{$\begin{array}{l}\text { BNT } \\
0,05\end{array}$} \\
\hline & & & $\begin{array}{c}\mathrm{N}_{0} \\
\text { Kontrol }\end{array}$ & $\begin{array}{c}\mathrm{N}_{1} \\
150 \mathrm{~kg} / \mathrm{h}\end{array}$ & $\begin{array}{c}\mathrm{N}_{2} \\
250 \mathrm{~kg} / \mathrm{h}\end{array}$ & $\begin{array}{c}\mathrm{N}_{3} \\
350 \mathrm{~kg} / \mathrm{h}\end{array}$ & \\
\hline Panjang buah & & 73 & $2,47 \mathrm{a}$ & $3,52 \mathrm{~b}$ & $3,76 \mathrm{~b}$ & $2,97 \mathrm{~b}$ & 0,56 \\
\hline Diameter buah & & 73 & $2,37 \mathrm{a}$ & $3,76 \mathrm{~b}$ & $3,60 \mathrm{~b}$ & $3,11 \mathrm{~b}$ & 0,78 \\
\hline Jumlah buah & & 73 & $1,17 \mathrm{a}$ & $1,45 \mathrm{~b}$ & $1,59 \mathrm{~b}$ & $1,32 \mathrm{~b}$ & 0,33 \\
\hline Berat buah & & 73 & $1,38 \mathrm{a}$ & $3,28 \mathrm{~b}$ & $3,73 \mathrm{~b}$ & $3,82 \mathrm{~b}$ & 0,78 \\
\hline $\begin{array}{l}\text { Produksi } \\
\text { Hektar (ton) }\end{array}$ & Per & 73 & $0,27 \mathrm{a}$ & $0,34 \mathrm{~b}$ & $0,36 \mathrm{~b}$ & $0,30 \mathrm{~b}$ & 0,08 \\
\hline
\end{tabular}


Tabel 11 menunjukan bahwa panjang buah yang terbaik dijumpai pada dosis NPK $250 \mathrm{~kg} / \mathrm{ha}\left(\mathrm{N}_{2}\right)$ umur 73 HST yang tidak berbeda nyata dengan dosis NPK $150 \mathrm{~kg} / \mathrm{ha}\left(\mathrm{N}_{1}\right)$ dan NPK $350 \mathrm{~kg} / \mathrm{ha}\left(\mathrm{N}_{3}\right)$. Namun berbeda nyata dengan kontrol $\left(\mathrm{N}_{0}\right)$. Hal ini diduga bahwa jika unsur hara yang tersedia dalam jumlah yang cukup untuk pertumbuhan akan menyebabkan kegiatan penyerapan hara dan fotosintesis berjalan dengan baik sehingga fotosintat yang terakumulasi juga ikut meningkat dan akan berdampak terhadap panjang buah. Jumini, (2006) dalam Noza et al, (2014) menyatakan bahwa pembentukan dan perpanjangan buah sangat dipengaruhi oleh ketersedian unsur hara $\mathrm{P}$ untuk proses fotosintesis yang menghasilkan karbohidrat, lemak, protein, mineral dan vitamin yang akan ditranslokasikan kebagian penyimpanan buah.

Diameter buah pada dosis NPK 150 $\mathrm{kg} / \mathrm{ha}\left(\mathrm{N}_{1}\right)$ tidak berbeda nyata dengan dosis NPK $250 \mathrm{~kg} / \mathrm{ha}\left(\mathrm{N}_{2}\right)$ dan dosis NPK 350 $\mathrm{kg} / \mathrm{ha}\left(\mathrm{N}_{3}\right)$. Namun, berbeda nyata dengan kontrol $\left(\mathrm{N}_{0}\right)$. Hal ini diduga bahwa pemberian pupuk NPK yang memiliki unsur hara dan pemberian dolomit yang dapat menetralkan $\mathrm{pH}$ tanah sehingga menghasilkan unsur hara $\mathrm{P}$, yang secara keseluruhan menyumbang hara pada bagian tanaman terutanam pada bagian batang. Winarso, (2005) dalam Noza et al, (2014) menambahkan dalam penelitiannya bahwa fosfor $(\mathrm{P})$ sangat berpengaruh dalam proses pertumbuhan dan pembentukan hasil, dimana fosfor berfungsi dalam transfer energi dan proses fotosintesis.

Selanjutnya Setyamidjaja (2006) dalam Benyamin dan Maruapey (2015), menambahkan bahwa $\mathrm{N}$ berperan dalam mempercepat pengubahan karbohidrat menjadi protein yang berpengaruh pada pembelahan, pemanjangan, dan pembesaran

Menurut Syamsudin et al. (2010) dalam Benyamin dan Maruapey (2015), menjelaskan bahwa unsur hara fosfor sel baru sehingga mempercepat pembuahan. Sedangkan ketersediaa unsur hara $\mathrm{P}$ dalam pupuk akan mempercepat pembungaan, dan pemasakan buah atau biji yang terlihat dari jumlah buah yang terbentuk, sedangkan $\mathrm{K}$ membantu meningkatkan kualitas hasil berupa bunga, buah, rasa dan warna menghasilkan karbohidrat dan protein yang berguna untuk pertumbuhan buah, sehingga dapat mempengaruhi pembesaran ukuran buah dan diameter buah

Jumlah buah pada dosis NPK 150 $\mathrm{kg} / \mathrm{ha}\left(\mathrm{N}_{1}\right)$ tidak berbeda nyata dengan dosis NPK $250 \mathrm{~kg} / \mathrm{ha}\left(\mathrm{N}_{2}\right)$ dan dosis NPK 350 $\mathrm{kg} / \mathrm{ha}\left(\mathrm{N}_{3}\right)$. Namun, berbeda nyata dengan kontrol $\left(\mathrm{N}_{0}\right)$. Hal ini diduga bahwa pemberian NPK pada tanah gambut dan kandungan hara yang dapat mensuplai pada parameter jumlah buah. Selanjutnya ditegaskan oleh Isbandi, D., (1993) dalam Prayitno (2015) menyatakan bahwa tanggapan tanaman terhadap unsur hara menunjukkan maksimal pada batas-batas tertentu dan pada jumlah yang lebih tinggi atau terlalu rendah justru akan menghasilkan produksi tanaman akan menurun karena pertumbuhannya terhambat atau unsur tersebut berubah sifat menjadi racun bagi tanaman.

Berat buah pada dosis NPK 250 $\mathrm{kg} / \mathrm{ha}\left(\mathrm{N}_{2}\right)$ umur 73 HST yang tidak berbeda nyata dengan dosis NPK $150 \mathrm{~kg} / \mathrm{ha}\left(\mathrm{N}_{1}\right)$ dan $350 \mathrm{~kg} / \mathrm{ha}\left(\mathrm{N}_{3}\right)$. Namun, berbeda nyata dengan kontrol $\left(\mathrm{N}_{0}\right)$. Produksi per hektar (ton) hasil tanaman okra pada dosis NPK $250 \mathrm{~kg} / \mathrm{h}\left(\mathrm{N}_{2}\right)$ tidak berbeda nyata dengan dosis NPK $150 \mathrm{~kg} / \mathrm{ha}\left(\mathrm{N}_{1}\right)$, dan $350 \mathrm{~kg} / \mathrm{ha}$ $\left(\mathrm{N}_{3}\right)$. Namun, berbeda nyata dengan kontrol $\left(\mathrm{N}_{0}\right)$. Hal ini diduga bahwa unsur hara makro seperti N, P dan K merupakan unsur hara esensil bagi tanaman, ketiga unsur ini bereran penting dalam meningkat pertumbuhan dan produksi tanaman.

berfungsi untuk mengubah karbohidrat seperti dalam perubahan tepung menjadi gula. Hasil perubahan karbohidrat tersebut 
akan berperan dalam pembentukan buah baik ukuran buah maupun beratnya, jika ketersediaan unsur fospor dalam tanah tersedia bagi tanaman maka akan menambah ukuran dan berat buah hasil panen. Selain itu, fospor mampu meningkatkan kemampuan akar untuk menyerap unsur hara seperti $\mathrm{N}$, dan $\mathrm{K}$. Dimana fungsi nitrogen dan kalium sebagai pembentuk klorofil yang berguna sekali dalam proses fotosintesis, dengan adanya proses fotosintesis tersebut maka tanaman dapat menghasilkan karbohidrat dan protein yang berguna untuk pembentukan buah yang dapat mempengaruhi pembesaran buah yang meliputi ukuran dan berat buat serta dapat meningkatkan hasil produksi tanaman okra.

\section{KESIMPULAN}

Dosis dolomit berpengaruh sangat nyata terhadap tinggi tanaman, diameter batang dan jumlah daun tanaman okra umur 15, 30, 45 dan 60 HST. Berpengaruh sangat nyata terhadap panjang buah okra umur 73 HST dan berpengaruh nyata terhadap berat buah umur73 HST, namun berpengaruh tidak nyata terhadap diameter buah, jumlah buah umur dan produksi per hektar (ton) 73 HST. Pupuk NPK berpengaruh sangat nyata terhadap tinggi tanaman dan diameter batang umur 15, 30, 45 dan 60 HST. Berpengaruh sangat nyata terhadap panjang buah dan diameter buah okra umur 73 HST. Berpengaruh tidak nyata terhadap jumlah buah, berat buah dan produksi perhektar (ton) okra umur 73 HST. Tidak terdapat interaksi antara dolomit dan pupuk NPK dari semua perlakuan.

\section{DAFTAR PUSTAKA}

Benyamin H, dan Maruapey A. 2015. Pertumbuhan dan Produksi Tanaman Terung (Solanum melongena L.) pada Berbagai Dosis Pupuk Organik Limbah Biogas Kotoran Sapi.
Universitas Muhamaddiyah. Sorong. ISSN : 1907-7556.

Elizabeth K. 2013. Pengaruh pupuk organik dan pupuk NPK terhadap $\mathrm{pH}$ dan Ktersedia tanah dan serta serapan-K, pertumbuhan dan hasil padi sawah (Oryza sativa L.). Universitas Patimura.

Firmansyah I, Syakir M, dan Lukman L. 2016. Pengaruh Kombinasi Dosis Pupuk N, P, dan K terhadap Pertumbuhan dan Hasil Tanaman Terung (Solanum melongena L.). Badan Penelitian dan Pengembangan Pertaian. Jawa Barat.

Kuswandi. 2005. Pengapuran Tanah Pertanian. Kanisus. Yogyakarta.

Hanafiah KA. 2013. Dasar-dasar Ilmu Tanah. Jakarta, PT Rajagrafindo Persada.

Noza LA, Yetti H, dan Khoiri MA. 2014. Pengaruh Pemberian Dolomit dan Pupuk N, P, K terhadap Pertumbuhan dan Produksi Tanaman Jagung Manis (Zea mays saccharata Sturt) di Lahan Gambut. Fakultas Pertanian Universitas Riau. Vol 1 No 2.

Maftuah E. Azwar M, Abdul S, dan Benito HP. 2013. Efektivitas Amelioran pada Lahan Gambut Terdegradasi untuk Meningkatkan Pertumbuhan dan Serapan NPK Tanaman Jagung Manis (Zea mays L. var. saccharata). Universitas Gajah Mada. Yogyakarta. Muhammad C, Ichsan P, Riskiyandika dan Wijaya I. 2015. Respon Produktifitas Okra (Abelmoschus esculentus) terhadap Pemberian Dosis Pupuk Petroganik dan Pupuk N. Fakultas pertanian. Universitas Muhamadiyah. Jember.

Nurhayati. 2011. Pengaruh Jenis Amelioran terhadap Efektivitas dan Infektivitas Mikroba pada Tanah Gambut dengan Kedelai Sebagai Tanaman Indikator. Agroteknologi. Fakultas pertanian. 
Universitas Syiah Kuala Darusalam. Banda Aceh.

Nyanjang R, Salim AA, dan Rahmiati Y. 2003. Penggunaan Pupuk Majemuk NPK 25-7-7 terhadap Peningkatan Produksi Mutu pada Tanaman Teh Menghasilkan di tanah Andisol. PT. Perkebunan Nusantara XII Prosiding Teh.

Prayitno A. 2015. Respon Pemberian Kapur Dolomit dan Pupuk Organik Granule Moderen terhadap Pertumbuhan dan Hasil Bawang Merah (Allium ascalonicum L.) pada Tanah Berpasir. Universitas Muhammaddiyah. Palangkaraya.

Putra DE, Yetty Y, dan Saputra SI. 2012. Pengaruh Sisa Dolomit dan Pupuk NPK terhadap Pertumbuhan dan Produksi Tanaman Caisim (Brassica chinensis) di Lahan Gambut.
Setiawan P. 2008. Pengaruh Pemberian Pupuk Dolomit terhadap Produksi etah Kopal di Gunung Walat Sukabumi. Departemen Silvikultur. Fakultas Kehutanan. Institut Pertanian Bogor.

Surmarwan S, dan Arman Y. 2015. Pengaruh Kapur Dolomite terhadap Nilai Resistivitasi Tanah Gambut. Pontianak: Universitas Tanjung Pura. ISSN: 2337-8206.

Wahyunto, Ritung S, Suparto, Subagjo H. 2005. Peat Land Distribution and Carbon Content in Sumatra and Kalimantan. Wetland InternationalIndonesia Program and Wildlife Habitat Canada (WHC). Bogor Indonesia.

Widodo. 2000. Pupuk yang Akrab Lingkungan, dalam Majalah Komoditas Edisi Khusus, Tahun II, 3 26 Januari 2000. 